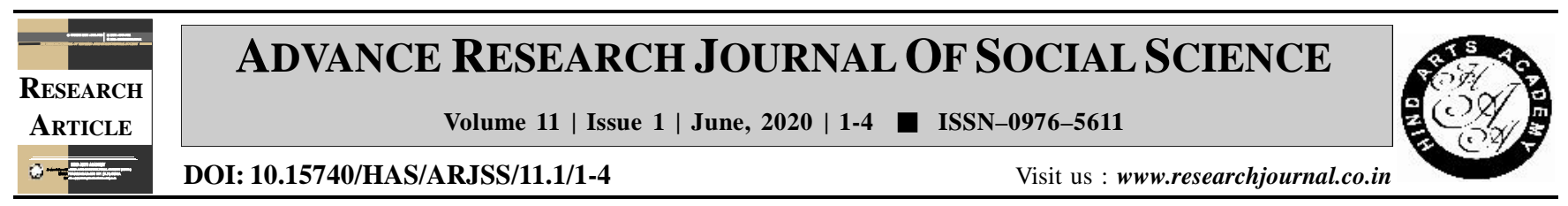

\title{
A comparative study on self-esteem among tribal adolescent boys and girls in Adilabad district of Telangana state
}

K. Samhitha* and P. Sreedevi

Department of Human Development and Family Studies, Professor Jayashankar Telangana State Agricultural University, Hyderabad (Telangana) India

(Email : samhitha.k33@gmail.com)

\section{ARTICLE INFO :}

$\begin{array}{lll}\text { Received } & : & 11.02 .2020 \\ \text { Revised } & : & 15.04 .2020 \\ \text { Accepted } & : & 01.05 .2020\end{array}$

KEY WORDS :

Tribes, Tribal adolescents,

Self-esteem, Rosenberg scale

HOW TO CITE THIS ARTICLE :

Samhitha, K. and Sreedevi, P. (2020). A comparative study on self-esteem among tribal adolescent boys and girls in Adilabad district of Telangana state. Adv. Res. J. Soc. Sci., 11 (1): 1-4, DOI: 10.15740/HAS/ ARJSS/11.1/1-4.Copyright@ 2020:Hind Agri- Horticultural Society

\section{ABSTRACT}

Self-esteem is defined as the attitude towards oneself and what one thinks of himself. The aim of the present study was to compare self-esteem among tribal adolescent girls and boys in Adilabad district of Telangana state. The size of the sample was 120 adolescents which includes 60 girls and 60 boys in the age range of 13-19 years were selected using purposive random sampling method.An ex-post factor research design was used for the study. Rosenberg's self-esteem scale was to assess the self-esteem of tribal adolescents. The data analysed using frequencies, percentages, means, SD's and ' $t$ ' test. The results have shown that, half of the adolescents had high level of selfesteem and the remaining half had average level of self-esteem. None of the adolescents exhibited low level of self-esteem. Girls scored comparatively higher than that of boys in self-esteem. 